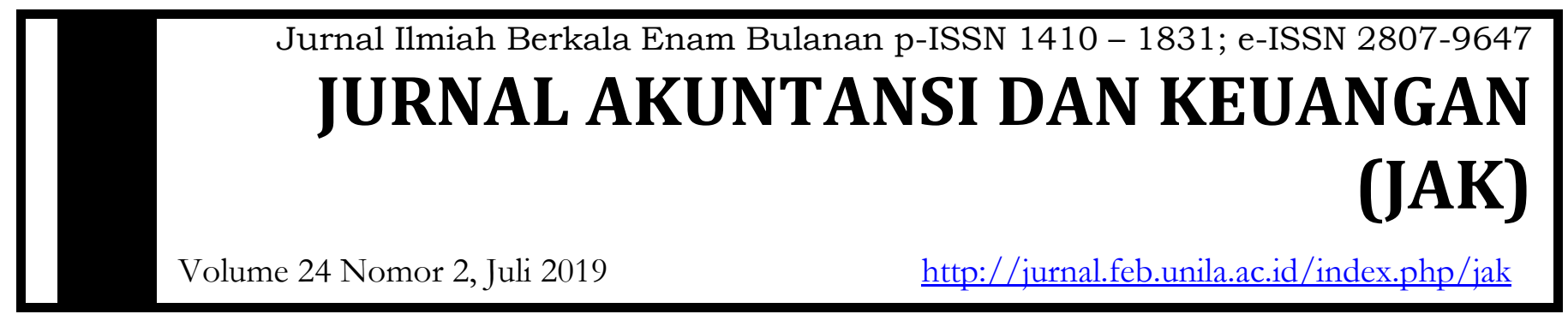

\title{
PERAN MODERASI KONVERGENSI IFRS DALAM HUBUNGAN ANTARA AGRESIVITAS PELAPORAN KEUANGAN DAN RETURN
}

\author{
Saring Suhendro ${ }^{1}$ \\ ${ }^{1}$ Fakultas Ekonomi dan Bisnis Universitas Lampung
}

\section{Informasi Naskah}

Update Naskah:

Dikumpulkan: 19 Sept 2018;

Diterima: 22 January 2019;

Terbit/Dicetak: 30 March 2019.

\section{Keywords:}

IFRS convergence, investor perceptions, return

\section{Abstract}

The purpose of this study is to examine the effect of accrual information quality and the role of IFRS convergence on earnings informativeness measured by ERC in relation to stock price movements occurring in Indonesia. Using manufacturing companies that went public and were listed on the Indonesia Stock Exchange in 2004-2013. The use of sample companies in 2004-2007 was before the IFRS convergence and in 2008-2013 after the IFRS convergence. The results showed that earnings response coefficient on earnings information decreased due to reported earnings containing high discretionary accruals. While investor perceptions (ERC) increased after the IFRS convergence. 


\section{A. PENDAHULUAN}

Ikatan Akuntansi Indonesia (IAI) telah mengumumkan bahwa International Financial Report Standards (IFRS) diadopsi di Indonesia pada tahun 2012 melalui konvergensi (IAI, 2011). Konvergensi ini dilakukan dalam berbagai tahap. Tahun 2007, IAI menerbitkan Pernyataan Standar Akuntansi Keuangan (PSAK) yang telah dikonvergensi dengan IFRS dan mulai diterapkan sebagai tahap pertama pada tahun 2008. Proses ini terus berlanjut hingga tahun 2012 dengan merevisi PSAK yang mengadopsi IFRS.

Konvergensi IFRS ke dalam PSAK akan berdampak besar bagi dunia usaha, terutama dari sisi pengambilan kebijakan perusahaan yang didasarkan kepada data-data akuntansi. Suatu perusahaan akan memiliki daya saing yang lebih besar ketika mengadopsi IFRS dalam laporan keuangannya. Upaya konvergensi standar akuntansi ke IFRS ini dilakukan agar standar akuntansi di Indonesia dapat meningkatkan kualitas informasi keuangan khususnya informasi laba.Konvergensi IFRS yang menekankan pada nilai wajar (fair value) akan menghasilkan laba akuntansi dan merupakan signal bahwa laporan keuangan memiliki nilai relevansi dan kualitas laba yang lebih tinggi (Ball, 2006).

Kualitas laba dapat ditunjukkan dengan agresivitas pelaporan keuangan yang lebih rendah. Semakin tinggi agresivitas pelaporan keuangan maka semakin rendah kualitas laba (Barth, Landsman, dan Lang, 2008). Agresivitas pelaporan keuangan merupakan aktivitas manajemen dalam rangka menaikkan/menurunkan laba akuntansi namun masih dalam batas generally accepted accounting principles (Frank et al., 2009).

Aktivitas ini menunjukkan kesempatan opportunistik manajer dalam memanipulasi laba akuntansi untuk memperoleh keuntungan pribadi sehingga menyebabkan informasi laba akuntansi nilainya menjadi kurang relevan (La Porta et al., 1997).

Sloan (1996) mendokumentasikan bahwa saham yang memiliki akrual positif atau laba yang meningkat, maka pada tahun berikutnya return-nya cenderung rendah.Collins dan Hribar (2000) mengkonfirmasi temuan ini dengan menggunakan data akrual kuartalan. Interpretasi dari temuan ini bahwa akrual menunjukkan simpton dari manajemen laba, tetapi investor tidak menyadari hal tersebut dan meyakini bahwa profitabilitas periode berikutnya akan tetap tinggi. Beberapa peneliti menguji apakah mispricing dapat disebabkan oleh akrual yang mencerminkan perilaku opportunistik manajemen (akrual diskresioner). Jones (1991) mengembangkan model untuk menghitung komponen akrual diskresiner dan non-diskresioner. Subranyaman (1996) dan Xie (2000) menunjukkan bahwa komponen akrual diskresioner memprediksi return, namun untuk komponen non-diskresioner tidak diuji.

Subramanyam (1996) menggunakan model Jones (1995) menunjukkan bukti bahwa akrual diskresioner pada periode berjalan berdampak positif terhadap reaksi pasar. Reaksi pasar terhadap kualitas laba ditunjukkan dengan besarnya abnormal return saham atas laba yang dilaporkan perusahaan atau dikenal dengan earnings response coefficient (Scott, 2000). Imhoff dan Lobo (1992) menemukan bukti empiris bahwa semakin berkualitas laba suatu perusahaan maka semakin tinggi persepsi investor yang ditunjukkan dengan ERC yang positif. Demikian juga sebaliknya, semakin rendah kualitas laba maka semakin rendah koefisien ERC. Hal ini membuktikan bahwa informasi terkait dengan kualitas laba yang dilaporkan akan mempengaruhi persepsi investor.

Defond dan Park (2001) menguji pengaruh abnormal akrual terhadap respon pasar yang dilihat dari koefisien ERC nya. Perusahaan yang melaporkan good news dengan abnormal working capital accrual yang menaikkan laba, maka ERC akan semakin rendah bila dibandingkan dengan melaporkan abnormal working capital accrual yang menurunkan laba. Sedangkan dampak penerapan IFRS (fair value accounting) pada hubungan return-earnings telah diuji oleh Kip (2009). Pengaruh IFRS diuji menggunakan model regresi untuk dua periode tahun berbeda dan industri berbeda, yaitu industri keuangan, asuransi, dan real estate yang paling banyak dipengaruhi oleh fair value accounting. Sedangkan penggunaan fair value accounting secara insidental adalah industri manufaktur dan industri lainnya. Temuannya menunjukkan bahwa IFRS ((fair value accounting) berdampak ERC yang positif. 
Di Indonesia penelitian yang meneliti dampak dari konvergensi IFRS pada hubungan return-earnings dalam rangka menguji apakah konvergensi IFRS pada perusahaan manufaktur memiliki dampak terhadap ERC belum pernah dilakukan. Hanya sedikit penelitian terdahulu yang menguji hubungan laba-return terkait dengan adopsi IFRS dan penelitian terdahulu lebih banyak memfokuskan pada salah satu elemen tertentu dan menghubungkannya dengan ERC (Kip, 2009).

Penelitian ini menggunakan ukuran ERC dari regresi return-earningsuntuk mengukur persepsi investor terhadap kualitas laba. Penelitian ini menguji pengaruh informasi kualitas akrual dan peran konvergensi IFRS terhadap keinformatifan laba yang diukur dengan ERCdalam hubungan dengan pergerakan harga saham yang terjadi di Indonesia. Peneliti memfokuskan pada satu pengukuran akrual diskresioner sebagai indikator penting yang berhubungan dengan kualitas laba. Oleh karena itu, penelitian mengenai pengaruh akrual diskresioner pada laba terhadap kualitas laba (ERC)dengan konvergensi IFRS sebagai variabel pemoderasi merupakan konteks yang lebih powerfull untuk mempelajari bagaimana meningkatkan keinformatifan informasi akuntansi.

Beberapa studi menyatakan bahwa IFRS tidak hanya berdampak pada level negara, tetapi juga berdampak terhadap perusahaan (Chua et al, 2010; Adika dan Anggraini, 2012, dan Latif, 2012). Oleh karena itu, penelitian ini akan meneliti dampak konvergensi IFRS pada level perusahaan.

Penelitian menggunakan sampel sebanyak 669 tahun amatan pada perusahaan manufaktur yang terdaftar di Bursa Efek Indonesia periode 2004-2008. Penelitian ini mengestimasi akrual diskresioner menggunakan model Jones (1991)yang dimodifikasi oleh Dechow et al., (1995) menggunakan ROA untuk mengontrol operasi perusahaan sebagaimana yang disarankan oleh Kothari et al. (2005). Peneliti menggunakan perubahan laba $(\Delta \mathrm{NI})$ atau unexpected earnings dalam model karena laba komponen transitori hanya temporer dan hanya mempengaruhi laba tahun ini saja sehingga akan mempengaruhi arah ERC (Freeman dan Tse, 1992; Easton dan Zmijewski, 1989). $\Delta$ NI merupakan perbedaan antara laba sebelum extraordinary items untuk tahun ini dan tahun lalu. Peneliti memasukan beberapa variabel kontrol yang berhubungan dengan karakteristik perusahaan melakukan manajemen laba, yaitu ukuran perusahaan, leverage, dan pertumbuhan.

Regresi dilakukan dengan menggunakan dua model, yaitu model pertama tanpa variabel kontrol dan model kedua memasukkan variabel kontrol. Hasilnya, baik pada model pertama dan model kedua menunjukkan bahwa akrual diskresioner menurunkan kualitas laba yang ditunjukkan dengan koefisien $\beta_{3}$ $(E R C)$ bernilai negatif. Temuan ini mengindikasikan bahwa investor mempersepsikan akrual diskresioner negatif dan dianggap mengurangi kualitas laba. Sedangkan setelah penerapan konvergensi IFRS sejak tahun 2008 nilai koefisien $\beta_{4}$ bernilai positif, hal ini menunjukkan bahwa investor mempersepsikan lebih percaya pada laba yang dilaporkan sehingga kualitas laba meningkat. Temuan ini memberikan bukti empiris bahwa bahwa IFRS ((fair value accounting) berdampak pada ERC pada perusahaan manufaktur di Indonesia.

Penelitian ini memberikan beberapa kontribusi penting. Pertama, bagi investor yang menganggap evaluasi kualitas laba yang diakibatkan dari tingkat agresivitas pelaporan keuangan ketika membuat keputusan investasi. Jika investor memberikan perhatian khusus pada saat akan menginvestasikan dananya, maka mereka harus menginvestigasi apakah perusahaan tersebut melakukan agresivitas pelaporan keuangan melalui akrual diskresioner.

Kedua, bagi literatur akuntansi dapat memperkuat pengembangan teori positif bidang ilmu akuntansi khususnya yang berhubungan dengan praktek keuangan dalam hubungannya dengan pemberlakuan sebuah standar akuntansi serta dampaknya terhadap pemangku kepentingan perusahaan.Akhirnya, bagi regulator untuk terus mengadopsi standar akuntansi mengacu pada standar IFRS.

Bagian selanjutnya dari penelitian ini diorganisasikan seperti berikut ini. Bagian 2 membahas mengenai tinjauan pustaka dan pengembangan hipotesis. Bagian 3 akan membahas mengenai metodologi penelitian. Sedangkan untuk pembahasan hasil dan kesimpulan dijelaskan pada bagian 4 dan 5 . 


\section{B. LANDASAN TEORI DAN PENGEMBANGAN HIPOTESIS}

\section{Teori Keagenan}

Teori keagenan banyak digunakan sebagai teori yang mendasari penelitian-penelitian di bidang akuntansi. Teori ini menunjukkan hubungan antara principal (pemilik sumber dana) dan agent (manajemen). Teori ini menjelaskan adanya pemisahan fungsi dalam pengelolaan dan pengambilan keputusan antara kedua belah pihak (Jensen dan Meckling, 1976). Hubungan kedua belah pihak yaitu principal-agent diikat dalam suatu kontrak (contracting theory) dimana agent berperan mewakili principal dalam pembuatan keputusan-keputusan bisnis dan memaksimumkan kesejahteraan pemegang saham. Hubungan para pihak tersebut membentuk agency relationship (Watts dan Zimmmerman, 1986).

Dalam konteks hubungan tersebut, kedua pihak berusaha memaksimumkan kepentingan masingmasing sehingga muncul potensi agency problem. Agent memiliki potensi besar untuk memaksimumkan kepentingannya dalam kontrak jangka pendek yang dimotivasi oleh beberapa hal. Salah satu motivasi manajemen laba adalah adanya bonus dan insentif yang manajer peroleh yang didasarkan atas kinerja perusahaan yang diukur dengan laba yang dihasilkan (Healy dan Wahlen, 1999). Manajemen laba yang didasarkan pada motivasi ini akan menimbulkan potensi besar yaitu manajemen akan melakukan manajemen laba perusahaan yang akan menguntungkan pihak-pihak tententu (Jensen dan Meckling, 1976). Penyebab manajemen laba ini karena adanya asymetric information antara manajer dan pemegang saham maupun manajer dan pihak eksternal perusahaan (Jensen dan Meckling, 1976).Asymetric information ini terjadi karena manajemen perusahaan memiliki informasi lebih tentang kondisi perusahaan dibandingkan dengan para pemegang saham.

Namun, pemegang saham dapat membatasi perilaku manajer melalui proses monitoring. Proses ini dilakukan dalam rangka memastikan bahwa manajemen tidak melakukan tindakan tertentu yang menyimpang atau cenderung membahayakan perusahaan. Upaya ini menimbulkan biaya monitoring (Jensen dan Meckling, 1976).

\section{Agresivitas Pelaporan Keuangan}

Agresivitas pelaporan keuangan merupakan aktivitas manajemen dalam rangka memanipulasi (menaikan/menurunkan) laba akuntansi yang masih dalam batas generally accepted accounting principles (Frank et al, 2009).Manipulasi laba merupakan suatu tindakan manajemen yang dengan sengaja mengambil langkah-langkah tertentu untuk melaporkan laba sampai pada tingkatan yang diinginkan. Aktivitas manajemen laba merupakan tindakan manipulasi laba dengan cara menggunakan keleluasaan manajemendalam pelaporan sesuai dengan yang standar akuntansi dan aktivitas yang terstruktur dalam cara yang tidak akan menurunkan nilai perusahaan.

Schipper (1989) berpendapat bahwa manajemen laba merupakan suatu bentuk campur tangan manajemen terhadap proses pelaporan keuangan dengan tujuan untuk memperoleh keuntungan tertentu. Bentuk campur tangan ini bisa mengambil bentuk angka-angka yang dinyatakan sesuai dengan pemilihan kebijakan pelaporan atau akrual diskresioner. Bentuk campur tangan manajemen terhadap pelaporan keuangan akan mengubah laporan yang dilaporkan dapat bertujuan untuk menyesatkan pengguna laporan ataupun untuk mempengaruhi hasil kontrak yang bergantung pada angka akuntansi yang dilaporkan (Healy dan Wahlen, 1999).

Manipulasi angka-angka dalam laporan keuangan menurunkan kualitas laporan itu sendiri karena dapat memberikan informasi yang menyesatkan dan tidak menggambarkan kondisi perusahaan yang sesungguhnya. Apabila laba yang dilaporkan tidak mencerminkan keadaan mendasar dari keadaan ekonomi perusahaan melainkan keinginan manajemen sendiri, maka kualitas laba pada laporan keuangan akan berkurang (Levitt,1998).

Penggunaan akrual dalam mendeteksi manajemen laba merupakan suatu langkah yang selama ini digunakan dan dipercaya keakuratannya dalam melakukan deteksi. Akrual diskresioner digunakan sebagai proksi untuk mendeteksi manajemen laba dengan menggunakan beberapa model ekspektasi akrual seperti 
Model Jones (1991), modified Jones (1995), Kasznik (1999), DeFond (2001), Yoon dan Miller (2002), Kothari et al. (2005), Gul dan Jaggi (2005).

\section{Earnings Response Coefficient (ERC)}

ERC merupakan ukuran hubungan antara laba dan return saham. ERC mengukur keinformatifan laba dalam hubungan dengan return saham. Volatilitas yang sering digunakan oleh peneliti untuk melihat hubungan antara informasi laba yang dilaporkan perusahaan dengan reaksi pasar dalam merespon informasi tersebut. ERC juga mengukur seberapa banyak informasi baru tentang kandungan laba dan informasi diukur dengan menguji pengaruh terhadap return saham sekitar tanggal pengumuman. Namun, beberapa peneliti menguji hubungan antara laba dan return selama satu tahun. Selain itu, mereka juga menggunakan ERC sebagai ukuran hubungan antara unexpected earnings dan unexpected return (Easton dan Zmijewski, 1989, Collins dan Kothari, 1989).

Ball dan Brawn (1968) menunjukkan bukti empiris bahwa terjadi fenomena abnormal return dalam hubungan antara informasi laba dengan respon pasar. Reaksi pasar dapat dilihat dari nilai koefisien ERC, sebagaimana yang diteliti oleh Kormendi dan Lipe (1987). Penelitian Kormendi dan Lipe (1987) menunjukkan bahwa laba dan ERC berhubungan positif dengan atribut laba perusahaan secara time series. Dechowet al. (1994) mengaitkan akuntansi akrual dengan ERC yang juga menangkap adanya fenomena abnormal return.

Abnormal returndari pasar modal dapat diidentifikasi dari good news perusahaan yang berdampak positif terhadap abnormal return, dan bad news perusahaan yang berdampak negatif terhadap abnormal return. Respon pasar terhadap good news maupun bad news atas informasi laba dapat diukur menggunakan ERC. ERC mengukur tingkat abnormal return pasar dalam merespon komponen laba unecpected yang dilaporkan dari perusahaan yang menerbitkan saham. Semakin tinggi ERC, maka investor akan memandang kinerja perusahaan dimasa depan akan lebih baik dibandingkan kinerja periode berjalan (Ramakrishnan dan Thomas, 1991).

Defond dan Park (2001) menguji dampak akrual diskresioner yang diantisipasi oleh ERC. Apabila pasar mengantisipasi adanya akrual pada suatu perusahaan maka pengaruh akrual tersebut dapat dilihat dari harga saham dan ERC. Defond dan Park (2001) mengekspektasi bahwa perusahaan yang melaporkan good news dengan peningkatan modal kerja akrual diskresioner akan memiliki ERC yang lebih rendah dibandingkan dengan perusahaan yang melaporkan bad news dengan penurunan modal kerja akrual diskresioner. Hasilnya menunjukkan bahwa perusahaan yang melaporkan bad news dengan peningkatan laba pada modal kerja akrual diskresioner akan meningkatkan ERC daripada perusahaan yang melaporkan bad news dengan laba yang menurun modal kerja akrual diskresioner. Pasar mengantisipasi akrual diskresioner tersebut dalam harga saham.

\section{Konvergensi IFRS}

Implementasi IFRS di Indonesia masih tahap konvergensi bukan adopsi penuh IFRS. Standar yang telah dikeluarkan mengacu pada praktek IFRS adalah PSAK tentang instrumen keuangan. Pada konvergensi IFRS fase pertama (2008 - 2012), per 1 Desember 2012 DSAK IAI telah menerbitkan: 40 PSAK, 20 ISAK, dan 11 PPSAK berikut revisi terkait serta 10 PSAK Syariah.

Tujuan konvergensi IFRS adalah untuk menghasilkan laporan keuangan yang berkualitas dan memiliki tingkat kredibilitas yang tinggi (IAI, 2011). Adopsi IFRS akan memberikan manfaat bagi investor yaitu: pertama, IFRS akan memberikan informasi akuntansi yang lebih akurat, lebih komprehensif dan lebih tepat waktu. Kedua, IFRS akan mengurangi biaya yang digunakan untuk mengolah informasi akuntansi karena dapat diperbandingkan secara internasional. Ketiga, pasar akan menjadi lebih efiesien sebab biaya yang digunakan untuk menganalisa laporan keuangan menjadi lebih rendah. Keempat, IFRS menghilangkan perbedaan standar akuntansi, yang secara langsung membuka peluang untuk terjadinya transaksi ekuitas antar negara .Kelima, adopsi IFRS dapat menurunkan risiko yang disebabkan oleh asimetri informasi sebagai akibat dari meningkatnya kualitas informasi akuntansi (Ball, 2006). 
Laba yang dipengaruhi oleh akuntansi nilai wajar karena pengukuran berikutnya dari aset dan impairment menyebabkan keuntungan atau kerugian. Apabila sebagian besar aset yang dimiliki perusahaan harus diukur menggunakan nilai wajar, maka kemungkinan besar laba akan berfluktuasi tergantung pada kondisi pasar. Pada saat kerugian akibat impairment maka perusahaan harus mengakui dengan segera keuntungan atau kerugian tersebut. Dengan demikian, laba dipengaruhi oleh akuntansi nilai wajar dan berpengaruh pula ke return saham.

Meskipun penerapan IFRS yang mengacu pada fair value menimbulkan pro dan kontra namun penelitian dibidang ini masih terus dilakukan untuk mencapai suatu kesimpulan manfaat keberadaan IFRS.Pendukung akuntansi fair value mengklaim bahwa fair value dapat menambah relevansi nilai informasi laporan keuangan, dengan menjadikannya lebih berguna bagi investor untuk tujuan penilaian perusahaan (Barth et al. 2001; Barth, 2004; Ball, 2006).Penelitian yang menyelidiki konsekuensi pelaporan keuangan dari penerapan IFRS seperti Barth et al. (2008) menyatakan bahwa laba akuntansi lebih informatif (nilai) dan kualitas yang lebih tinggi setelah penerapan IFRS.

Beberapa penelitian di beberapa negara berbeda menunjukkan praktek manajemen laba tidaklah berkurang setelah mengadopsi IFRS (van Tendeloo dan Vanstraelen, 2005; Jeanjean dan Stolowy, 2008; Paananen, 2008; Kabir, Laswad dan Islam, 2010). Ahmed, Neel dan Wang (2013) berpendapat bahwa fleksibilitas yang terkandung dalam IFRS menyebabkan pengadopsiannya tidaklah meningkatkan kualitas laba yang dilaporkan. Selanjutnya, ketika pertimbangan manajemen membuat pengakuan suatu transaksi diperketat (manajemen laba akrual), itu cenderung mendorong manajer untuk mencari cara melakukan manajemen laba dengan transaksi yang lebih terstruktur (Schipper, 2003).

\section{Kerangka Konseptual}

Penelitian ini menguji dampak manajemen laba terhadap persepsi investor yang diukur dengan koefisien ERC dan dirumuskan dalam hipotesis pertama (H1). Sedangkan pengaruh konvergensi IFRS dalam hubungan antara return dan laba untuk melihat dampak konvergensi IFRS dalam pergerakan koefisien ERC ditunjukkan dalam hipotesis kedua (H2). Variabel kontrol yang digunakan dalam model ini adalah ukuran perusahaan (size), leverage perusahaan (lev), dan pertumbuhan perusahaan (growth). Hal ini dilakukan untuk melihat pilihan alternatif manajemen untuk melakukan praktek manajemen laba ketika pilihan terhadap metode tertentu dibatasi (Watts dan Zimmerman, 1986; (Siregar dan Utama, 2008; danPurwanti, 2011).

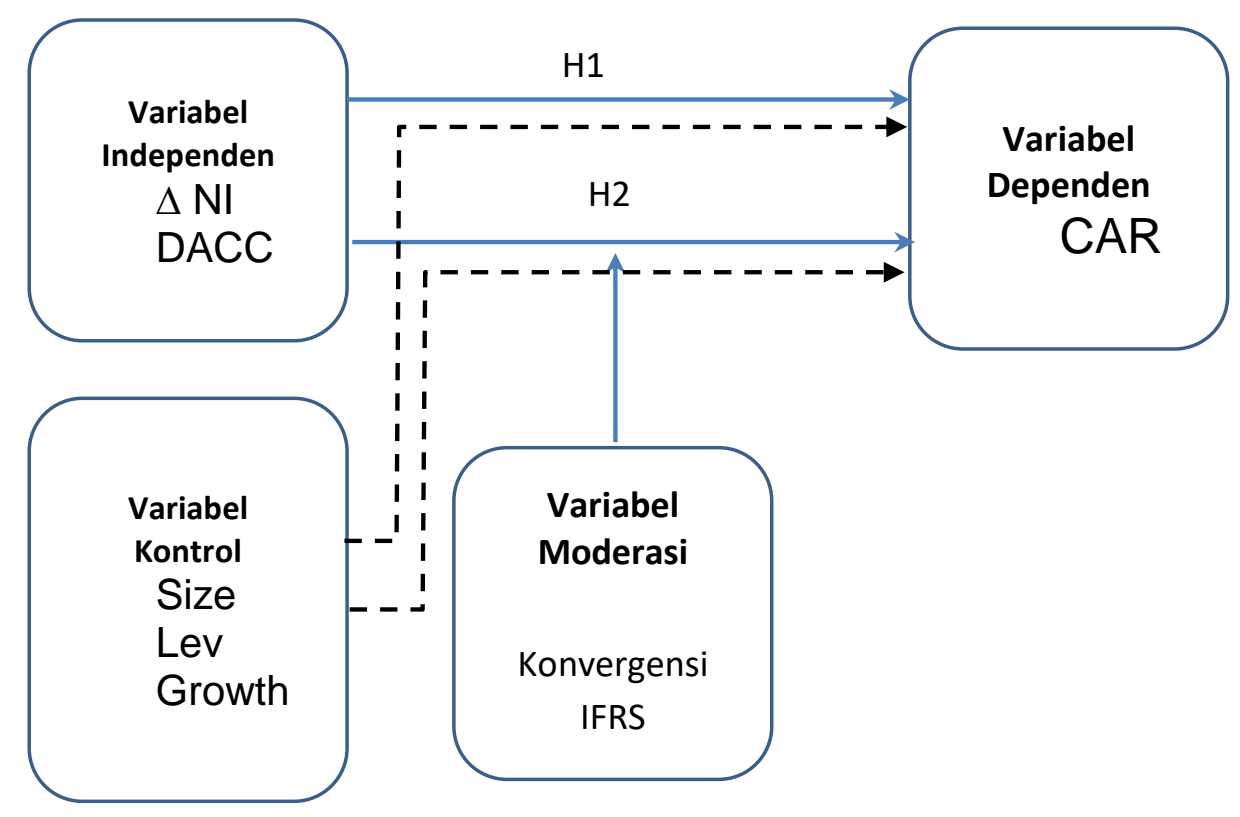

Gambar 1.Kerangka Konseptual 


\section{Pengembangan Hipotesis}

\section{Hubungan Agresivitas Pelaporan Keuangan dan Kualitas Laba}

Perusahaan mempengaruhi dan memanipulasi laba yang dilaporkan melalui pilihan kebijakan akuntansi atau dikenal dengan akrual diskresioner. Akrual diskresioner yang merupakan residual akrual digunakan sebagai ukuran tingkat manajemen laba.Jones (1991) membagi akrual menjadi normal accrual (non-diskresioner) dan abnormal discretionary (akrual diskresioner) dengan melakukan model regresi time series. Residual dari regresi diatribusikan ke diskresioner manajemen laba.

Sloan (1996) dan Xie (2001) menemukan bahwa akrual secara umum memiliki power untuk memprediksi return saham periode berikutnya. Hal ini menunjukkan bahwa manajemen laba yang disebabkan oleh akrual diskresioner tidaklah direspon baik oleh pasar (investor) sebagai good news. Semakin tinggi akrual diskresioner (manajemen laba) yang dilakukan oleh perusahaan, maka semakin rendah harga saham.

Defond dan Park (2001) menguji dampak akrual diskresioner yang diantisipasi oleh ERC. Apabila pasar mengantisipasi adanya akrual pada suatu perusahaan maka pengaruh akrual tersebut dapat dilihat dari harga saham dan ERC. Defond dan Park (2001) mengekspektasi bahwa perusahaan yang melaporkan good news dengan peningkatan modal kerja akrual diskresioner akan memiliki ERC yang lebih rendah dibandingkan dengan perusahaan yang melaporkan bad news dengan penurunan modal kerja akrual diskresioner. Hasilnya menunjukkan bahwa perusahaan yang melaporkan bad news dengan peningkatan laba pada modal kerja akrual diskresioner akan meningkatkan ERC dibandingkan perusahaan yang melaporkan bad news dengan laba yang menurun modal kerja akrual diskresioner. Pasar mengantisipasi akrual diskresioner tersebut dalam harga saham. Temuan Defond dan Park (2001) membuktikan bahwa pasar tidak sepenuhnya menyesuaikan pada implikasi harga.

Hasil penelitian terdahulu menyimpulkan bahwa agresivitas pelaporan keuangan yang dilakukan oleh perusahaan akan menghasilkan laba yang lebih tinggi/rendahdapat mengurangi kredibilitas dari informasi laba yang dilaporkan. Praktek manajemen laba ini (yang diproksikan dengan akrual diskresioner) berdampak pada menurunnya kepercayaan pasar (investor) dalam keputusan investasi. Berdasarkan hubungan persepsi antara kualitas laba dan akrual diskresioner.

Karena ERC merupakan proksi dari persepsi pasar terhadap kualitas laba, makaakrual diskresioner yang mencerminkan kualitas laba akan dipersepsikan negatif oleh investor. Hipotesis pertama dirumuskan sebagai berikut:

\section{H1: investor mempersepsikan negatif terhadap kualitas laba (akrual diskresioner)}

\section{Pengaruh Konvergensi IFRS dalam Hubungan antara Agresivitas Pelaporan Keuangan dan Kualitas Laba}

Penerapan IFRS (fair value accounting)diyakini dapat meningkatkan kualitas informasi laporan keuangan yang dipublikasikan karena manajer ditekan untuk membuat suatu laporan yang benar dan jujur serta dibatasi dalam aktivitas manajemen laba (Hoque, Easton dan van Zijil, 2014). Penggunaan konsep fair value pada pelaporan keuangan akan menjadikan informasi lebih informatif dikarenakan lebih sering terjadinya fluktuasi harga dan dilakukan penyesuaian harga maka seharusnya ERC menjadi lebih tinggi (Kip, 2009). Temuan Kip (2009) menunjukkan bahwa IFRS mempengaruhi ERC. ERC yang lebih tinggi menunjukkan informasi yang lebih kepada investor dan akan dipersepsikan laba lebih persisten.

Chua et al (2012) menyatakan bahwa kualitas akuntansi akan mengalami peningkatan berdasarkan penuruan earnings management dan meningkatnya timely loss recognition. Latif (2012) menunjukkan terjadinya peningkatan informasi setelah adopsi IFRS di Uni Eropa. Armstrong et al. (2010)menginvestigasi respon investorterhadap informasi laba dengan menguji reaksi pasar modalmenggunakan ukuran ERC terhadap peristiwa adopsi IFRS dilakukan di negara Eropa. Hasil penelitianArmstrong et al. (2010) menunjukkan bahwa pasar merespon positif terhadap peningkatan kualitas informasi akuntansi setelah adopsi IFRS. Investor dapat bereaksi positif terhadap informasi laba 
IFRS apabila investor berharap bahwa penerapan IFRS dapat menghasilkan kualitasinformasi laba yang lebih tinggi, relatif terhadap penerapan standar akuntansilokal. Sedangkan Paglietti (2009) dan Gebhardt \& Farkas (2011) menginvestigasi value relevance dari informasi akuntansi sebelum dan sesudah mengimplementasikan IFRS secara mandatori. Hasil kedua penelitian tersebut menunjukkan bahwa kualitas informasi akuntansi meningkat setelah mengadopsi IFRS.

Berdasarkan argumen dan hasil penelitian terdahulu maka dapat disimpulkan bahwa dengan adanya interaksi antara konvergensi IFRS dengan agresivitas pelaporan keuangan akan meningkatkan kualitas laba. Hal ini terjadi karena konvergensi IFRS akan membatasi pelaporan akrual diskresioner yang agresif dan menekan perilaku opportunistik manajemen sehingga menghasilkan laba yang lebih persisten dan mempengaruhi informasi laba perusahaan. Berkenaan dengan informasi laba tersebut, maka investor akan merespon positif kinerja perusahaan yang ditunjukkan dengan reaksi pasar lebih baik.

Berdasarkan hubungan persepsi antara kualitas laba dan akrual diskresioner, peneliti menduga konvergensi IFRS mempengaruhi kualitas laba. Semakin banyak standar akuntansi yang dikonversi ke IFRS dan diimplementasikan oleh perusahaan dari tahun ke tahun, maka investor mempersepsikan kualitas laba akan meningkat (menurun). Dengan semakin banyaknya PSAK yang dikonvergen ke IFRS maka perilaku manajemen laba diduga akan menjadi lebih sulit dibandingkan dengan sebelum konvergen ke IFRS (Adika dan Anggraita, 2013). Oleh karena itu, diharapkan koefisien $\beta_{4}$ berbeda dari nol.

\section{H2: persepsi investor terhadap kualitas laba meningkat setelah konvergensi IFRS}

\section{METODE PENELITIAN}

\section{Populasi dan Sampel}

Populasi dalam penelitian ini adalah perusahaan manufaktur yang go publik dan terdaftar di Bursa Efek Indonesia pada tahun 2004-2013. Penelitian ini hanya membatasi pada perusahaan manufaktur karena model untuk mengukur praktek manajemen laba dikembangkan untuk menguji praktek itu pada perusahaan-perusahaan manufaktur. Penggunaan sampel perusahaan tahun 2004-2007 adalah sebelum konvergensi IFRS dan tahun 2008-2013 setelah konvergensi IFRS. Pemilihan sampel penelitian menggunakan metode purposive sampling. Kriteria yang digunakan adalah:

1. Perusahaan manufaktur yang terdaftar di BEI selama periode tahun 2004-2013 secara berturut-turut;

2. Menerbitkan laporan keuangan tahunan yang mencakup laporan posisi keuangan, laporan rugi laba serta laporan arus kas secara lengkap; dan

3. Laporan keuangan berakhir pada tanggal 31 Desember.

Dua hipotesis yang telah dikembangkan akan diuji secara empiris dengan menggunakan metode multiple linear regression. Data keuangan perusahaan-perusahaan yang digunakan diambil dari Datastream dan akan diuji dengan menggunakan Eviews 6.

\section{Definisi Operasional Variabel}

\section{Return}

Variabel dependen dalam penelitian ini adalah cummulative market-adjusted return (CAR). Untuk menghitung CAR maka perlu dihitung:

a. Return aktual saham adalah return yang sesungguhnya terjadi pada saat atau tanggal tertentu pada periode pengamatan, pada penelitian ini adalah return pada selama 15 bulan yaitu tiga bulan setelah tahun berakhirnya fiskal.

b. Return abnormal (abnormal return), menggunakan market adjusted return model adalah perbedaan antara return ekspetasi dengan return pasar, yang dirumuskan menjadi:

\begin{tabular}{|c|c|}
\hline \multirow{2}{*}{\multicolumn{2}{|c|}{$\begin{array}{l}\mathbf{A} \mathbf{R}_{\mathbf{i}, \mathbf{t}} \\
\text { Dimana: }\end{array}$}} \\
\hline & \\
\hline $\mathrm{AR}_{\mathrm{i}, \mathrm{t}}$ & $=$ Abnormal Return saham i padaperiodet \\
\hline $\mathrm{R}_{\mathrm{i}, \mathrm{t}}$ & $=$ Return aktual saham i padaperiodet \\
\hline $\mathrm{Rm}, \mathrm{t}$ & $=$ Return pasarpadaperiodet \\
\hline
\end{tabular}


Model tersebut digunakan dengan anggapan bahwa penduga yang terbaik untuk mengestimasi return saham adalah indeks harga pasar pada saat itu, dengan demikian return abnormal adalah return yang melebihi return pasar (Schweitzer, 1989 dalam Mulyani et al., 2007). Sedangkan return pasar diwakili dengan Indeks Harga Saham Gabungan (IHSG) yang dihitung secara tahunan dengan rumus:

$$
\mathrm{Rm}=\frac{\left(\mathrm{IHSG}_{\mathrm{t}}-\mathrm{IHSG}_{\mathrm{t}-1}\right)}{\mathrm{IHSG}_{\mathrm{t}-\mathrm{i}}}
$$

Di mana:

$\mathrm{Rm} \quad \quad=$ Return pasar

$\mathrm{IHSG}_{t} \quad=$ Indeks harga saham gabungan pada periode $t$

$\mathrm{IHSG}_{t-1}=$ Indeks harga saham gabungan pada periode $t-1$

Return aktual saham periode dihitung dengan rumus:

$$
\mathrm{R}_{\mathrm{i}, \mathrm{t}}=\frac{\left(\mathrm{P}_{\mathrm{i}, \mathrm{t}}-\mathrm{P}_{\mathrm{i}, \mathrm{t}-1)}\right)}{\mathrm{P}_{\mathrm{i}, \mathrm{t}-\mathrm{1}}}
$$

Di mana:

$$
\begin{aligned}
& \mathrm{R}_{i, t}=\text { Return saham } i \text { pada periode } t \\
& \mathrm{P}_{i, t}=\text { Harga saham } i \text { pada periode } t \\
& \mathrm{P}_{i, t-1}=\text { Harga saham } i \text { pada periode } t-1
\end{aligned}
$$

Kemudian, rumus perhitungan CAR adalah:

$$
\mathrm{CAR}_{\mathrm{it}}=\sum \mathrm{AR}_{\mathrm{it}}
$$

Dimana: $\mathrm{AR}_{\mathrm{it}}=$ abnormal return untuk saham $i$ pada periode $t$

\section{Agresivitas Pelaporan Keuangan}

Proksi dari agresivitas pelaporan keuangan menggunakan akrual diskresioner. Akrual diskresioner diestimasi menggunakan model Jones (1991) yang dimodifikasi (Dechow et al., 1995) menggunakan ROA untuk mengontrol operasi perusahaan sebagaimana yang disarankan oleh Kothari et al., (2005).Dechow et al. (1995) membuktikan bahwa Modified Jones Model lebih unggul dibandingkan dengan model manajemen laba akrual lainnya. Untuk menghitung akrual diskresioner dilakukan regresi untuk memperoleh nilai residual. Tahap penghitungannya adalah sebagai berikut:

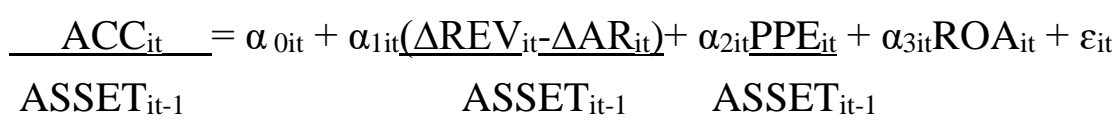

Keterangan:

$\begin{array}{ll}\mathrm{ACC}_{\mathrm{it}} & : \text { Total akrual perusahaan } i \text { pada periode } t \\ \mathrm{ASSET}_{\mathrm{it}-1} & : \text { Total asset perusahaan } i \text { pada periode } t \\ \Delta \mathrm{REV}_{\mathrm{it}} & : \text { selisih pendapatan perusahaan } i \text { pada periode } t \text { dibandingkan periode } t-1 \\ \Delta \mathrm{AR}_{\mathrm{it}} & : \text { selisih piutang usaha perusahaan } i \text { pada periode } t \text { dibandingkan periode } t-1 \\ \mathrm{PPE}_{\mathrm{it}} & : \text { grossproperty, plant and equipment perusahaan } i \text { pada periode } t \\ \mathrm{ROA}_{\mathrm{it}} & : \text { laba sebelum extraordinary item perusahaan } i \text { pada periode } t \\ \varepsilon_{\mathrm{it}} & : \text { akrual diskresioner perusahaan } i \text { pada periode } t \\ \alpha_{0} & : \text { konstanta } \\ \alpha_{1-3 \mathrm{it}} & : \text { koefisien }\end{array}$

\section{Konvergensi IFRS}

Untuk meneliti di bidang konvergensi IFRS ke dalam PSAK di Indonesia tidak dapat digunakan metode sebelum dan sesudah adopsi IFRS, melainkan hanya dapat melihat trend dari tahun ke tahun saja seperti yang dikutip dari pernyataan beberapa ahli terkait dengan konvergensi IFRS di Indonesia yaitu Dr. 
Ratna Wardhani, Dosen Pasca Sarjana Ilmu Akuntansi Fakultas Ekonomi dan Bisnis Universitas Indonesia, (2014) menyatakan bahwa "Indonesia menerapkan strategi konvergensi dalam pengadopsian IFRS ke dalam PSAK, Indonesia tidak menggunakan strategi Big Bang seperti di Australia atau Hongkong... sehingga penelitian terkait dengan konvergensi IFRS di Indonesia hendaknya fokus pada dampak sebelum dan sesudah dari standar aturan tertentu dalam PSAK yang telah dikonvergensikan dengan IFRS atau fokus untuk melihat trend dampak dari konvergensi dari tahun ke tahun".

Pendapat yang serupa juga dikemukana oleh ahli lainnya yang memperkuat pendapat ahli pertama (Dr. Sylvia Veronica Siregar, anggota Dewan Standar Akuntansi Keuangan dan Dosen Pasca Sarjana Ilmu Akuntansi Fakultas Ekonomi dan Bisnis Universitas Indonesia, 2014), menyatakan bahwa: "Proksi yang digunakan untuk melihat tren konvergensi IFRS di Indonesia, dapat menggunakan variabel dummy $1,2,3$,..dan seterusnya untuk mewakili tahun $t$ tersebut."

Dengan demikian, dapat disimpulkan bahwa untuk mengukur variabel proses konvergensi IFRS ke dalam PSAK yang terjadi di Indonesia ditandai dengan melihat trend proses konvergensi dari tahun ke tahun dengan menggunakan variabel dummy dengan skala nominal yang menunjukkan tahun periode tahap awal sampai dengan setelah disahkannya aturan PSAK yang telah dikonvergensi dengan IFRS yaitu (2008, $2009,2010, \ldots, 2013)=(1,2,3, \ldots, 6)$.Angka konvergensi IFRS yang semakin besar menunjukkan asumsi bahwa semakin banyak standar akuntansi keuangan yang telah disesuaikan dengan IFRS.

\section{Variabel Kontrol}

Variabel kontrol yang digunakan pada penelitian ini adalah 1) leverage. Leverage menunjukkan bahwa perusahaan menggunakan pembiayaan eksternal yang digunakan untuk pendanaan operasi dan perluasanatau memproksikan pengaruh kewajiban atas kontrak-kontrak yang telah mengikat perusahaan. Memasukkan leverage konsisten dengan debt covenant hypothesis yang menyatakan bahwa perusahaan memiliki kecenderungan untuk melakukan manajemen laba ketika ada kemungkinan untuk melanggar perjanjian kontrak karena adanya pinjaman dari pihak lain (Watts dan Zimmerman, 1986). Variabel ini diproksikan dengan debt-to-asset ratio; 2) ukuran perusahaan (size)menunjukkan besar kecilnya perusahaan yang ditunjukkan oleh total aktiva dan merupakan proksi kemampuan informatif atas harga. Perusahaan-perusahaan yang besar memiliki insentif yang lebih besar dalam melakukan manajemen laba dibandingkan dengan perusahan yang kecil oleh karena perusahaan dengan ukuran yang lebih besar mendapatkan perhatian lebih banyak dari investor dibandingkan dengan perusahaan yang lebih kecil (Siregar dan Utama, 2008). Ukuran perusahaan diwakili logaritma total aset; 3) Pertumbuhan penjualan (growth). Pertumbuhan penjualan menunjukkan tingkat pertumbuhan penjualan perusahaan. Oleh karena perusahaan memiliki prospek pertumbuhan perusahaan dimasa depan, maka dorongan untuk melakukan manajemen laba pun diduga terjadi (Purwanti, 2011). Pertumbuhan penjualan diukur dengan total penjualan $_{t}$-penjualan ${ }_{t-1}$ dibagi dengan penjualan ${ }_{\mathrm{t}-1}$.

\section{Model Empiris}

Untuk menguji hipotesa $\mathrm{H}_{1}$ dan $\mathrm{H}_{2}$, maka digunakan estimasi regresi menggunakan model sebagai berikut:

$$
\mathrm{CAR}_{\mathrm{it}}=\beta_{0}+\beta_{1} \Delta \mathrm{NI}_{\mathrm{it}}+\beta_{2} \mathrm{DACC}_{\mathrm{it}}+\beta_{3} \Delta \mathrm{NI}_{\mathrm{it}} * \mathrm{DACC}_{\mathrm{it}}+\beta_{4} \Delta \mathrm{NI}_{\mathrm{it}} * \mathrm{DACC}_{\mathrm{it}} * \mathrm{IFRS}_{\mathrm{it}}+\beta_{5} \mathrm{IFRS}_{\mathrm{it}}+
$$

$$
\beta_{6} \text { SIZE }_{\text {it }}+\beta_{7} \text { LEVERAGE }_{\text {it }}+\beta_{8} \text { GROWTH }_{\text {it }}+\varepsilon_{\text {it }}
$$

Keterangan:
$\mathrm{CAR}_{\text {it }}$
$\triangle \mathrm{NI}_{\text {it }}$
:cumulative market-adjusted return perusahaan $i$ pada periode $t$
$\mathrm{DACC}_{\text {it }}$
: Laba bersih yang dilaporkan perusahaan $i$ pada periode $t$
$\Delta \mathrm{NI}_{\mathrm{it}}{ }^{*} \mathrm{DACC}_{\mathrm{it}}$
: akrual diskresioner perusahaan $i$ pada periode $t$
$\Delta \mathrm{NI}_{\mathrm{it}} * \mathrm{DACC}_{\mathrm{it}} * \mathrm{IFRS}_{\mathrm{it}}$
: interaksi antara laba dengan akrual diskresioner perusahaan $i$ pada periode $t$ (ERC)
: interaksi antara laba, akrual diskresioner, dan konvergensi
IFRSperusahaan i pada periode $t$
IFRS $_{\text {it }}$
: konvergensi IFRS perusahaan i pada periode $t$ 


$\begin{array}{ll}\text { SIZE }_{\text {it }} & : \text { total asset perusahaan } i \text { pada periode } t \\ \text { LEVERAGE }_{\text {it }} & : \text { rasio dana yang disediakan oleh kreditur perusahaan } i \text { pada } \\ & \text { periode } t \\ \text { GROWTH }_{\text {it }} & : \text { pertumbuhan penjualan perusahaan } i \text { pada periode } t \\ \text { ROA }_{\mathrm{i}} & : \text { laba sebelum extraordinary item perusahaan i pada periode } t \\ \beta_{0} & : \text { konstanta } \\ \beta_{1-9} & : \text { koefisien regresi }\end{array}$

Persamaan (2) dikembangkan untuk menguji dampak praktek manajemen laba akrual yang diproksikan dengan nilai akrual diskresionerterhadap persepsi investor yang ditunjukkan dengan koefisien ERC. Berdasarkan persamaan (2) diekspektasi interaksi antara $\Delta$ NI dan DACCatau koefisien $\left(\beta_{3}\right)$ akan memiliki tanda negatif. Untuk menguji $\mathrm{H} 2$ yaitu dampak konvergensi IFRS pada praktek manajemen laba akrual terhadap $E R C\left(\beta_{4}\right)$ dimana angka 1, 2, 3, 4, 5 dan 6 untuk tahun 2008-2013, sedangkan variabel konvergensi IFRSsebelum tahun 2008 akan menggunakan angka 0. Variabel nominal 1 sampai 6 digunakan untuk menunjukkan tingkat adopsi IFRS oleh perusahaan-perusahaan di Indonesia karena Indonesia mengkonvergensi IFRS secara bertahap dimulai dari tahun 2008. Periode tahun sebelum 2008 (2004-2007) akan digunakan angka 0 . Interaksi antara $\triangle$ NI, DACC, dan IFRS atau koefisien $\left(\beta_{4}\right)$ diharapkan akan memiliki tanda berlawanan (positif) atau berbeda dari nol.

\section{ANALISIS DAN PEMBAHASAN}

\section{Statistika deskriptif}

Sampel yang digunakan dalam penelitian ini adalah perusahaan yang terdaftar dari tahun 2004-2013 di Bursa Efek Indonesia dan tidak pernah mengalami delisting serta menyediakan semua data perusahaan yang diperlukan untuk pengujian empiris. Data diambil dari Datastream dari Pusat Data Ekonomi dan Bisnis FEB UI. Tabel 1 melaporkan ringkasan statistik deskriptif mean, median, max, min, dan standar deviasi dari keseluruhan sampel.

Tabel 1 StatistikDeskriptif

\begin{tabular}{lccccc}
\hline \multicolumn{1}{c}{ Variabel } & Mean & Median & Max & Min & Std. Dev. \\
\hline \hline CAR & 0,06 & 0,06 & 0,56 & $(1,24)$ & 0,12 \\
$\Delta \mathrm{NI}$ & 0,07 & 0,07 & 1,01 & $(1,43)$ & 0,13 \\
DACC & $(54,44)$ & $(53,04)$ & 179,55 & $(580.62)$ & 79,54 \\
IFRS & 2,10 & 2,00 & 6,00 & 0,00 & 2,17 \\
LEV & 34,67 & 31,50 & 280,06 & 0,04 & 27,21 \\
SIZE & 21,14 & 21,02 & 26,08 & 17,55 & 1,58 \\
GROWTH & 0,10 & 0,10 & 1,91 & $-1,79$ & 0,29 \\
\hline \hline
\end{tabular}

CAR adalah kumulatif return yang disesuaikan dengan pasar (cumulative market-adjusted return) untuk periode 12 bulan yang berakhir akhir tahun fiskal; $\Delta$ NIadalah perbedaan antara laba sebelum extraordinary item untuk tahun berjalan dan tahun lalu dibagi dengan total aset awal tahun. DACC adalah nilaiakrual diskresioner. IFRS adalah variabel nominal 0 untuk periode tahun sebelum 2008 dan 1, 2, 3,4,5, dan 6 untuk tahun 2008 sampai 2013; Lev adalah leverage perusahaan yang diukur dengan menggunakan debt to asset ratio; Size adalah ukuran perusahaan yang diukur denganlogaritma natural dari total aset pada tahun t; Growth adalah pertumbuhan penjualan yang diukur dengan total penjualan ${ }_{t} /$ penjualan $_{\mathrm{t}-1}$.

Tabel 2 melaporkan matriks korelasi pearson $(\rho)$ antara CAR, $\triangle$ NI, DACC, IFRS, dan variabel kontrol. Korelasi yang rendah antar variabel yang mengukur persepsi investor mengindikasikan bahwa 
perbedaan persepsi investor terhadap kualitas informasi akrual. Korelasi antara IFRS dan DACC positif dan signifikan $(\rho=0,302$, $p$-value $=0,000)$ menunjukkan bahwa IFRS mempengaruhi DACC secara positif.

Tabel 2 Pearson Correlation Matrix

\begin{tabular}{lccccccc}
\hline Variabel & CAR & $\Delta$ NI & DACC & IFRS & LEV & SIZE & GROWTH \\
\hline \hline CAR & 1 & & & & & & \\
$\Delta$ NI & 0,450 & 1 & & & & & \\
& $(0,000)$ & & & & & & \\
DACC & 0,095 & 0,014 & 1 & & & & \\
& $(0,014)$ & $(0,722)$ & & & & & \\
IFRS & 0,103 & 0,109 & 0,302 & 1 & & & \\
& $(0,008)$ & $(0.005)$ & $(0,000)$ & & & & \\
LEV & $-0,382$ & $-0,372$ & $-0,101$ & $-0,153$ & 1 & & \\
& $(0,000)$ & $(0,000)$ & $(0.009)$ & $(0,000)$ & & & \\
SIZE & 0,192 & 0,211 & 0,190 & 0,169 & 0,028 & 1 & \\
& $(0,000)$ & $(0,000)$ & $(0,000)$ & $(0,000)$ & 0,477 & & \\
GROWTH & 0,083 & 0,167 & 0,045 & 0,002 & $-0,171$ & 0,051 & 1 \\
& $(0,032)$ & $(0,000)$ & $(0,249)$ & $(0,962)$ & $(0,000)$ & $(0,185)$ & \\
\hline \hline
\end{tabular}

Pearson correlation matrix untuk variabel penelitian. CAR adalah kumulatif return yang disesuaikan dengan pasar (cumulative market-adjusted return) untuk periode 12 bulan yang berakhir akhir tahun fiskal; $\Delta$ NIadalah perbedaan antara laba sebelum extraordinary item untuk tahun berjalan dan tahun lalu dibagi dengan total aset awal tahun. DAcc adalah nilaiakrual diskresioner. IFRS adalah variabel nominal 0 untuk periode tahun sebelum 2008 dan 1, 2, 3,4,5, dan 6 untuk tahun 2008 sampai 2013; Lev adalah leverage perusahaan yang diukur dengan menggunakan Debt to Asset Ratio;Size adalah ukuran perusahaan yang diukur denganlogaritma natural dari total aset pada tahun $\mathrm{t}$; Growth adalah pertumbuhan penjualan yang diukur dengan total penjualan $/$ /penjualan t $-1 ._{\text {. }}$

Pengujian asumsi klasik ditujukan untuk melihat apakah model yang ada memenuhi persyaratan model regresi. Pengujian tersebut meliputi pengujian autokorelasi, heteroskedastitas, dan multikolineritas untuk memastikan bahwa parameter yang dihasilkan efisien.

Pengujian autokorelasi dilakukan dengan melakukan uji Breusch-Godfrey. Kriteria pengujian adalah apabila nilai $p$-value dari Chi-square uji $<5 \%$ maka terdeteksi adanya autokorelasi. Hasil pengujian persamaan pada lampiran 1 menunjukkan p-value $>5 \%$ yang menyatakan tidak adanya autokorelasi.

Untuk mendeteksi masalah heteroskedastisitas digunakan uji White Heteroskedasticity. Apabila pvalue dari scaled explained SS kurang dari 5\%, maka terdapat masalah heteroskedastisitas. Hasil pengujian seperti yang ditunjukkan oleh hasil pada lampiran 2 menunjukkan adanya masalah heteroskedastisitas. Oleh karena adanya masalah dan heteroskedastisitas, maka white estimator digunakan untuk mengatasi masalah tersebut. Hasil uji empiris dengan menggunakan OLS dan mengaplikasikan white estimator dapat dilihat pada Tabel 3.

Uji multikolinearitas dilakukan dengan membandingkan korelasi antar variabel independen dalam hal ini delta_ni, DACC IFRS, SIZE, LEV, dan GROWTH. Tabel 2 menunjukkan tidak adanya korelasi antar variabel independen yang melebihi 0.8. Dengan demikian dapat disimpulkan bahwa variabel-variabel independen dari yang akan diuji secara empiris terbebas dari masalah multikolinearitas.

\section{Persepsi Investor terhadap Agresivitas Pelaporan Keuangan}

Pengujian hipotesis pertama (H1) dan hipotesis kedua (H2) dilakukan menggunakan persamaan 2. Pengujian ini menggunakan dua regresi (model 1), yaitu regresi pertama tanpa memasukan variabel kontrol dan regresi kedua (model 2) dengan memasukkan variabel kontrol. Hasil pengujian empiris kedua regresi tersebut disajikan pada Tabel 3. 
Tabel 3 Earnings Response Coefficient dan Persepsi Investor

\begin{tabular}{|c|c|c|c|c|c|c|}
\hline Variabel & $\begin{array}{c}\text { Prediksi } \\
\text { tanda }\end{array}$ & Koef & \multicolumn{2}{|c|}{ Model 1} & \multicolumn{2}{|c|}{ Model 2} \\
\hline Intersep & 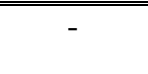 & $\bar{\beta}_{0}$ & $\begin{array}{l}0,0333 \\
(0000)\end{array}$ & & $\begin{array}{l}-0,1583 \\
(0,004)\end{array}$ & $* * *$ \\
\hline$\Delta \mathrm{NI}$ & + & $\beta_{1}$ & 0,2673 & & 0,1547 & \\
\hline & & & $(0,000)$ & $* * *$ & $(0,000)$ & **** \\
\hline DACC & - & $\beta_{2}$ & $\begin{array}{l}0,0002 \\
(0,000)\end{array}$ & & $\begin{array}{l}0,0001 \\
(0,024)\end{array}$ & \\
\hline$\Delta \mathrm{NI} * \mathrm{DACC}$ & - & $\beta_{3}$ & $\begin{array}{c}-0,0032 \\
(0,001)\end{array}$ & $* * *$ & $\begin{array}{c}-0,0031 \\
(0,000)\end{array}$ & $* * *$ \\
\hline$\Delta \mathrm{NI} * \mathrm{DACC} * \mathrm{IFRS}$ & + & $\beta_{4}$ & $\begin{array}{l}0,0005 \\
(0,010)\end{array}$ & $* * *$ & $\begin{array}{l}0,0004 \\
(0,018)\end{array}$ & **** \\
\hline IFRS & $?$ & $\beta_{5}$ & $\begin{array}{l}0,0031 \\
(0,119)\end{array}$ & & $\begin{array}{l}0,0009 \\
(0,643)\end{array}$ & \\
\hline SIZE & + & $\beta_{6}$ & & & $\begin{array}{l}0,0114 \\
(0,000)\end{array}$ & **** \\
\hline LEV & - & $\beta_{7}$ & & & $\begin{array}{c}-0,0011 \\
(0,000)\end{array}$ & *** \\
\hline GROWTH & + & $\beta_{8}$ & & & $\begin{array}{c}-0,0127 \\
(0,354)\end{array}$ & \\
\hline Adjusted R2 & & & 0,294 & & 0,352 & \\
\hline F-Statistic & & & 56.592 & $* * *$ & 4.257 & $* * *$ \\
\hline
\end{tabular}

CAR adalah kumulatif return yang disesuaikan dengan pasar (cumulative market-adjusted return) untuk periode 12 bulan yang berakhir akhir tahun fiskal; $\Delta$ NIadalah perbedaan antara laba sebelum extraordinary item untuk tahun berjalan dan tahun lalu dibagi dengan total aset awal tahun. DACC adalah nilaiakrual diskresioner. IFRS adalah variabel nominal 0 untuk periode tahun sebelum 2008 dan 1, 2, 3,4,5, dan 6 untuk tahun 2008 sampai 2013; Lev adalah leverage perusahaan yang diukur dengan menggunakan Debt to Asset Ratio; Size adalah ukuran perusahaan yang diukur denganlogaritma natural dari total aset pada tahun $\mathrm{t}$; Growth adalah pertumbuhan penjualan yang diukur dengan total penjualan ${ }_{\mathrm{t}} /$ penjualan $_{\mathrm{t}-1}$.

Nilai $p$-value ditunjukkan dalam tanda kurung.

*** signifikan pada level $0,01, * *$ signifikan pada level 0,05, dan *signifikan pada level 0,1.

Pada tabel 3 untuk model regresi 1, menunjukkan bahwa $\Delta \mathrm{NI}\left(\beta_{1}\right)$ berhubungan positif signifikan dengan return (CAR) yaitu sebesar 0,2673 dengan $p$-value $=0,000$. Hasil positif dan signifikan pada level 1 persen mengindikasikan bahwa perubahan laba meningkatkan persepsi investor terhadap keinformatifan laba. Setelah memasukan varibel kontrol (model regresi 2), hasil pengujian juga menunjukkan koefisien $\Delta \mathrm{NI}\left(\beta_{1}\right)$ yang positif signifikan yaitu 0,1547 dengan $p$-value 0,000 .

Hipotesis pertama (H1) menyatakan bahwa investor mempersepsikan negatif kualitas laba (akrual diskresioner). Persepsi investor terhadap akrual diskresioner yang mencerminkan return saham dapat dilihat pada tanda dan arah dari koefisien interaksi antara perubahan laba dan akrual diskresioner. Tabel 3 regresi 1 menunjukkan bahwa koefisien $\triangle \mathrm{NI}^{*} \mathrm{DACC}\left(\beta_{3}\right)$ atau $E R C$ adalah negatif signifikan pada level 1 persen yaitu $-0,0032$ ( $p$-value $=0,000)$.Koefisien $\left(\beta_{3}\right)$ juga negatif signifikan pada model regresi kedua pada yaitu $-0,0031$ ( $p$-value=0,000). Koefisien negatif signifikan mengindikasikan bahwa investor mempersepsikan bahwa dengan adanya akrual diskresioner akan mengurangi kualitas laba dan menurunkan return saham dimasa depan. Atau dengan kata lain, dengan investor mengetahui bahwa perusahaan melakukan manajemen laba (akrual diskresioner) maka keinformatifan laba akan berkurang. Jadi hipotesis pertama (H1) terdukung. Hal ini sejalan dengan penelitianSloan (1996); Xie (2001); danDefond dan Park (2001) yang menyatakan bahwa agresivitas pelaporan keuangan yang dilakukan oleh perusahaan akan menghasilkan laba yang lebih tinggi/rendah dapat mengurangi kredibilitas dari informasi laba yang dilaporkan.

Hasil penelitian ini juga mendukung temuan Imhoff dan Lobo (1992) bahwa semakin berkualitas 
laba suatu perusahaan maka semakin tinggi persepsi investor yang ditunjukkan dengan ERC yang positif. Hal ini membuktikan bahwa informasi terkait dengan kualitas laba yang dilaporkan akan mempengaruhi persepsi investor.

\section{Dampak IFRS terhadap Persepsi Investor}

Tabel 3, menguji hipotesis kedua (H2) apakah konvergensi IFRS akan meningkatkan keinformatifan laba. Peneliti menginteraksikan konvergensi IFRS dan akrual diskresioner dalam hubungan antara laba dan return saham. Pada kedua regresi tanpa atau dengan memasukan variabel kontrol interaksi ketiga variabel tersebut menunjukan koefisien yang nilai positif dan signifikan. Nilai koefisien interaksi dari $\triangle \mathrm{NI} * \mathrm{DACC} * \mathrm{IFRS}\left(\beta_{4}\right)$ atau ERC adalah positif signifikan sebesar 0,0005 pada regresi $(p$-value $=0,000)$ untuk regresi model 1 dan 0,0004 dengan $p$-value 0,018 dengan memasukan variabel kontrol.

Hasil diatas mengindikasikan bahwa setelah konvergensi IFRS maka meningkatkan kepercayaan investor pada informasi laba yang dilaporkan. Investor meyakini bahwa penerapan IFRS mampu mengurangi perilaku opportunistik manajer dalam mememanipulasi laba. Hasil penelitian ini menunjukkan bahwa konvergensi IFRS yang dilakukan secara bertahap dari tahun 2008 telah dapat mengurangi diskresi manajemen dan meningkatkan keinformatifan dari laba yang dilaporkan. Temuan ini sejalan dengan penelitian Kip (2009) yang menunjukkan secara jelas bahwa adopsi IFRS akan mempengaruhi ERC dan keinformatifan laba yang dilaporkan. Dengan demikian, hipotesis kedua terdukung.

Pelucio-Grecco et al. (2014) berpendapat bahwa suatu aturan akuntansi yang diterapkan dapat membatasi praktek manajemen laba apabila aturan tersebut memiliki tujuan untuk meningkatkan kualitas pelaporan dengan cara meningkatkan tingkat komparabilitas juga transparansi informasi yang dilaporkan tersebut. Aturan yang mengatur tersebut berupa standar akuntansi yang mengadopsi standar akuntansi internasional. Penurunan praktek manajemen laba akrual perusahaan dapat menjadi indikator mengenai efektivitas konvergensi aturan IFRS dapat menekan sikap oportunis manajemen sehingga menaikkan kualitas informasi keuangan yang dilaporkan (Pelucio-Grecco et al., 2014).

Persepsi investor terhadap IFRS dalam menekan praktek manajemen laba disebabkan oleh karena banyaknya pengungkapan yang diharuskan oleh IFRS (Van Zijl, dan Dunstan (2013). Berdasarkan hasil pengujian diatas, maka adopsi IFRS oleh perusahaan-perusahaan manufaktur di Indonesia mampu mengurangi praktek manajemen laba.Hwang, Chiou dan Wang (2013) menyatakan bahwa aturan yang menyangkut pengungkapan terbukti efektif dalam mengurangi praktek manajemen labakarena aturan yang efektif dapat membatasi diskresi manajemen dalam membuat laporan laba yang akan dipublikasikan (Pelucio-Grecco, 2014). Oleh karena itu, hasil penelitian ini mengindikasikan bahwa sejak tahun 2008 kualitas laba perusahaan manufaktur yang terdaftar di Indonesia telah mengalami peningkatan.

\section{E. SIMPULAN DAN SARAN}

Penelitian ini memfokuskan pada pengaruh konvergensi IFRS terhadap persepsi investor terhadap keinformatifan laba yang dilaporkan yang dilihat dari koefisien earnings response coefficient (ERC). Konvergensi IFRS di Indonesia telah dimulai sejak tahun 2008 dan secara bertahap terus dilakukan adopsi pada standar akuntansi keuangan yang ada ke IFRS.

Persepsi investor (ERC) terhadap informasi laba menurun disebabkan karena laba yang dilaporkan mengandung akrual diskresioner tinggi. Hal ini menunjukkan bahwa investor tidak memberikan kepercayaan pada laba tinggi setelah mengetahui adanya manajemen laba yang dilakukan oleh manajemen sebagai akibat perilaku opportunistik.

Persepsi investor (ERC) meningkat setelah konvergensi IFRS. Meningkatnya persepsi investor karena konvergensi IFRS diyakini dapat mengurangi praktek manajemen laba akrual perusahaan. Dengan berkurangnya manajemen laba akrual, investor dapat memperoleh informasi yang lebih berkualitas sehingga keputusan investasi yang dibuat akan lebih tepat. Keterbatasan penelitian ini adalah pada pemilihan sampel yang digunakan yaitu pada perusahaan manufaktur. Sedangkan industri manufaktur penggunaan fair value bersifat lebih insidental (Kip, 2009). Namun, penelitian ini menggunakan jenis 
industri manufaktur saja dan ada kemungkinan data penelitian ini terdapat sample selection bias.

Selain itu, penelitian ini tidak melakukan robustness test untuk menguji hasil uji empiris dengan membandingkannya dengan uji lain.

Penelitian selanjutnya dapat menggunakan sampel perusahaan keuangan, asuransi dan real estate yang merupakan jenis industri paling dipengaruhi oleh IFRS (fair value accounting) karena harus menilai sebagian besar aset dan kewajibannya menggunakan nilai wajar. Selain itu, penelitian selanjutnya dapat mengembangkan penelitian ini dengan melihat pengaruh konvergensi IFRS terhadap praktek DACC negatif yang menurunkan laba maupun DACC positif yang menaikan laba.

\section{REFERENSI}

Adika, Asri Widyawati dan Anggraita, Viska. 2013. Pengaruh Konvergensi IFRS Efektif Tahun 2011, Kompleksitas Akuntansi, dan Probabilitas Kebankrutan Perusahaan Terhadap Timelines dan Manajemen Laba. Paper pada Simposium Nasional Akuntansi di Manado.

Ahmed, Anwer, Neel, Michael, \& Wang, Dechun. 2013. Does Mandatory Adoption of IFRS Improve Accounting Quality? Preliminary Evidence.Contemporary Accounting Research, 30(4), 1344-1372.

Armstrong, C., Guay, W.R., dan Weber, J. 2010. The Role of Information and Financial Reporting in Corporate Governance and Debt Contracting. Journal of Accounting and Economics. 50. 179-234.

Ball, R. J. and P. Brown. 1968. An Empirical Evaluation of Accounting Income Numbers.Journal of Accounting Research 6, 159-178.

Ball, Ray. 2006. International Financial Reporting Standards (IFRS): pros and cons for investors. Accounting and Business Research, 36, 5-27

Barth M.E, Landman, W.R., Young, D., dan Zhuang, Z. 2014. Relevance of Differences between Net Income based on IFRS and Domestic Standards for European Firms. Journal of Business Finance \& Accounting. Vol 41, Issue 3-4, pages 297-327,

Bowen, R. Burgstahler, D., dan Daley. 1987. The Incremental Content of Accrual Versus Cash Flow Data. The accounting review.62,723-747.

Beaver, W.H. 1968.The information content of annual earnings announcement.Journal of Accounting Research Supplement to 6.67-92.

Callen, J.L dan Segal, D. 2004. Do Accruals Drive Firm-Level Stock Returns? A Variance Decomposition Analysis. Article online: 29 APR 2004.

Chua, Yi Lin (Elaine), et al. 2012. The Impact of Mandatory IFRS Adoption on Accounting Quality: Evidence from Australia. Journal of International Accounting Research, 11 (1): 119-146.

Collins, D., E. Maydew, and I. Weiss. 1997. Changes in the Value-Relevance of Earnings and Book Values over the Past Forty Years.Journal of Accounting and Economics, 24, 39-67

DeFond, M.L. and J. J. Jiambalvo. 1994. Debt Covenant Violation and Manipulation of Accruals.Journal of Accounting and Economics 17, 145-1476.

DeFond, M. L. and C. W. Park. 2001. The Reversal of Abnormal Accruals and The Market Valuation of Earnings Surprises.The Accounting Review 76, 375-404.

Frank, M.M., Linch, L.J., dan Rego, S.O.2009. Tax Aggresiveness and Its Relation to Aggresive Financial Reporting. The Accounting Review.vol. 84, no.2. 567-496.

Gebhardt, G., dan Farkas, Z.N. 2011. Mandatory IFRS Adoption and Accounting Quality of European Banks Journal of Business Finance \& Accounting, Vol. 38, Issue 3-4, pp. 289-333, 2011

Healy, Paul M, \& Wahlen, James M. 1999. A review of the Earnings Management Literature and ts implications for Standard Setting.Accounting Horizons, 13(4), 365-383.

Holler, Annette. (2008). Have Earnings Lost Value-Relevance? Revisiting Latest Evidence on EVA.The Business Review, Cambridge, 10(2), 245-254.

Houqe, Muhammad Nurul, Easton, Samuel, \& Zijl, Tony van. (2014). Does mandatory IFRS Adoption Improve Information Quality in Low Investor Protection Countries? Journal of International Accounting, Auditing and Taxation, Volume 23(2), Pages 87-97

Jones, J. 1991. Earnings Management During Import Relief Investigations.Journal ofAccounting Research 29, 193228.

Kip, Andre. 2009. The effect of Fair Value on the Earnings Response Coefficient. Master thesis. University of Amsterdam.

Kormendi dan Lippe. 1987. The Relation Between Stock Return and Accounting Earning Given Alternative Information. The Accounting Review 65.

La Porta, R., Lopez-de Silanes, F., Shhleifer A., Vishny, R. 1997. Legal Determinant of External Finance. TheJournal of Finance. 52. 1131-1150. 
Latif, Dwianto Muhktar. 2012. Pengujian Kualitas Informasi dan Asimetri Informasi Sebelum dan Sesudah Adopsi IFRS di Uni Eropa. Thesis. Magister Sains dan Doktor Ilmu-ilmu Ekonomi Fakultas Ekonomi dan Bisnis Universitas Gadjah Mada, Yogyakarta.

Levitt, Arthur. 1998. "The Numbers Game". Unpublished Remarks

Paglietti P.2009.The Value Relevance of Accounting Information in Italy Following IFRS Adoption, IR Top, VI, $n$. 4, October/December.

Pelucio-Grecco, Marta Cristina, Geron, Cecília Moraes Santostaso, Grecco, Gerson Begas, \& Lima, João Paulo Cavalcante. 2014. The Effect of IFRS on Earnings Management in Brazilian non-financial Public Ccompanies. Emerging Markets Review, 21, 42-66.

Purwanti, Ari. 2011. Pengaruh Insentif Ekspropriasi terhadap Pengelolaan Laba dengan Mempertimbangkan Transaksi Hubungan Istimewa, Keberadaan Pengendali dalam Manajemen, Efektifitas Dewan Komisaris dan Dewan Audit, Serta Pemegang Saham Terbesar Kedua. Disertasi PIA FE-Universitas Indonesia.

Rendleman, R.J. Jr., Jones, C.P., Latané, H.A. 1982. Empirical Anomalies Based on Unexpected Earnings and The Importance of Rrisk Adjustments.Journal of FinancialEconomics 10, 269-287.

Ramakrishnan, Ram, T.S dan Thomas, JK. 1991. Valuation of Permanent, Transitory, and Price-Irrelevant Component of Reported Earnings.

Schipper, Katherine. 1989. Commentary on Earnings Management. Accounting Horizons Subramanyam, K. R. 1996. The pricing of discretionary accruals.Journal of Accountingand Economics 22, 249-281.

Scoot, William. R. 2010. Financial Accounting Theory, Second Edition, Canada: Prentice Hall.

Sloan, R. G. 1996. Do Stock Prices Fully Reflect Information in Accruals and Cash Flowsabout Future Earnings?The Accounting Review 71, 289-316

Wilson, G. P. 1986. The Relative Information Content of Accruals and Cash Flows:Combined Evidence at The Earnings Announcement and Annual Report Release Date.Journal of Accounting Research 24, 165-200.

Wilson, G. P. 1987. The Incremental Information Content of Accrual and Funds Components of Earnings After Controlling for Earnings.The Accounting Review62, 293-322.

Whelan, Catherine, \& McNamara, Ray. 2004. The Impact of Earnings Management on the Value-relevance of Financial Statement Information.SSRN working paper.

Watts, R., \& Zimmerman, J. 1990. Positive Accounting Theory : A Ten Year Perspective. Accounting Review, 65(1), 131.

Xie, H. 2001. The Mispricing of Abnormal Accruals.The Accounting Review 76, 357-373.

\section{Lampiran 1}

Breusch-Godfrey Serial Correlation LM Test:

\begin{tabular}{llll}
\hline F-statistic & 2.211742 & Prob. F(2,658) & 0.1103 \\
Obs*R-squared & 4.467400 & Prob. Chi-Square(2) & 0.1071 \\
\hline
\end{tabular}

\section{Lampiran 2}

Heteroskedasticity Test: Breusch-Pagan-Godfrey

\begin{tabular}{llll}
\hline F-statistic & 21.38728 & Prob. F(8,660) & 0.0000 \\
Obs*R-squared & 137.7270 & Prob. Chi-Square(8) & 0.0000 \\
Scaled explained SS & 377.1913 & Prob. Chi-Square(8) & 0.0000 \\
\hline
\end{tabular}

